\title{
Septic Arthritis of the Hip in Lome (Togo)
}

\author{
Komi Cyrille Tagbor ${ }^{1 *}$, Viwale Etonam Sika Koffi-Tessio², Kodjo Kakpovi ${ }^{3}$, Prenam Houzou ${ }^{4}$, \\ Eyram Fianyo', Sadat Oniankitan'2, Awaki-Esso Atake ${ }^{2}$, Parou Kamkote'2, \\ Kokou Hefoume Amegan-Aho5, Owonayo Oniankitan'2, Moustafa Mijiyawa2
}

${ }^{1}$ Rheumatology Department, Be Hospital, Lome, Togo

${ }^{2}$ Rheumatology Department, Sylvanus Olympio Teaching Hospital, Lome, Togo

${ }^{3}$ Rheumatology Department, Tomde Regional Hospital, Kara, Togo

${ }^{4}$ Rheumatology Department, Kara Teaching Hospital, Kara, Togo

${ }^{5}$ Paediatric Department, Ho Teaching Hospital, Ho, Ghana

Email: *tcyrille18@yahoo.ca

How to cite this paper: Tagbor, K.C., Koffi-Tessio, V.E.S., Kakpovi, K., Houzou, P., Fianyo, E., Oniankitan, S., Atake, A.-E., Kamkote, P., Amegan-Aho, K.H., Oniankitan, O. and Mijiyawa, M. (2021) Septic Arthritis of the Hip in Lome (Togo). Open Journal of Rheumatology and Autoimmune Diseases, 11, 97-105.

https://doi.org/10.4236/ojra.2021.113012

Received: April 23, 2021

Accepted: June 27, 2021

Published: June 30, 2021

Copyright (๑) 2021 by author(s) and Scientific Research Publishing Inc. This work is licensed under the Creative Commons Attribution International License (CC BY 4.0).

http://creativecommons.org/licenses/by/4.0/

\begin{abstract}
Objectives: To determine the epidemiological, clinical, and bacteriological characteristics of septic arthritis of the hip (SAH) among patients hospitalized in the departments of Rheumatology in Lomé. Patients and Methods: This was a multicentre, descriptive study, conducted over a 16-year period, from January 2004 to December 2020 on patients' records at the three departments of Rheumatology in Lomé. We included in this study only patients with complete laboratory and radiological data. Patients who underwent hip replacement surgery and those with arthritis of the hip due to all inflammatory arthropathies were excluded. The diagnosis of SAH was based on clinical, radiological and bacteriological features. In the absence of bacteriological confirmation, the presumptive etiological diagnosis was based on epidemiological data, contacting with a person with tuberculosis, the presence of high-grade fever, the mode of presentation of the symptoms, the patient's general appearance, and the result of the tuberculin skin test. The data was collected using Epi info 7.0 and statistical analysis was performed using STATA/IC 11.0. Results: Out of 3776 patients hospitalized in the three departments over the study period, 705 (18.67\%) were diagnosed with septic arthritis of which $70(9.92 \%)$ patients with SAH. The 70 patients with SAH were $44(62.86 \%)$ females, and $26(37.14 \%)$ males, with a sex ratio of $1.7 \mathrm{~F} / \mathrm{M}$. The mean age of the patients was $42.43 \pm 19.37$ years (range: 5 years and 80 years) and the mean duration of symptoms was $6.57 \pm 8.85$ months (range: 2 days and 48 months). The pain was inflammatory in nature in $46(65.71 \%)$ and mechanical in nature in $24(34.29 \%)$ patients. The onset of the disease was progressive in $50(71.43 \%)$ patients and sudden in $20(28.57 \%)$ patients. The locations of the pain were: groin only 25 (35.71\%), greater trochanter only $15(21.43 \%)$, groin and lower back $14(20 \%)$, and groin and greater tro-
\end{abstract}


chanter 9 (12.86\%). Sixty-four patients $(91.43 \%)$ were limping and only six (08.57\%) were crippled. Weight loss was noted in 38 (54.29\%) patients. A risk factor was identified in $63(90.00 \%)$ patients; they were chronic alcohol abuse 24 (34.29\%), poor hygiene 17 (24.29\%), sickle cell disease 13 (18.57\%), HIV infection five (7.14\%), and diabetes four (05.71\%). Radiologic features suggestive of SAH were seen on plain radiograph and computed tomography in $55(78.57 \%)$ and $15(21.43 \%)$ patients, respectively. The SAH was unilateral (48 right hip and 20 left hip) in 68 (97.14\%) patients and bilateral in two $(02.86 \%)$ patients. The diagnosis of SAH was probable tuberculosis in 46 (65.71\%) patients and probable pyogenic bacteria in $24(34.29 \%)$ patients. The outcome was favourable in $68(97.14 \%)$ patients and two $(02.86 \%)$ patients died. Conclusion: The hip remains a relatively rare localization of infectious pathologies. Most cases of SAH are due to tuberculosis.

\section{Keywords}

Septic Arthritis, Hip, Togo, Africa

\section{Introduction}

Septic Arthritis of the Hip (SAH) refers to the infection of the synovial membrane of the hip joint [1] [2]. This excludes post-infectious arthritis and reactive arthritis [1] [2] [3]. In western countries, the main causative agents of SAH are bacteria, mostly Staphylococcus aureus [1]. The infection can result from hematogenous spread of the microorganism (primary SAH) [2] but in most cases, SAH is iatrogenic due to direct inoculation of the causative organism during intraarticular procedures [1] [2]. Infection of prosthetic joints can result from either direct inoculation or hematogenous spread [1]. Reports on Primary SAH are very rare in international literature and most are from Western countries [1]. In 1979, Rampon et al. reported 10 cases over eight years [3]. Evrard and Soudrie [2] in 1993 published 44 cases observed in 40 years and in 1981, 93 cases, representing $16 \%$ of peripheral septic arthritis, were recorded in 16 departments of rheumatology in a multicentre study [4]. African data on SAH are scarce. In Togo, a hospital-based study conducted in the northern region estimated SAH at $5.81 \%$ of osteoarticular infections [5]. The aim of this study is to determine the epidemiological, clinical, and bacteriological characteristics of septic arthritis of the hip (SAH) among patients hospitalized in the departments of Rheumatology in Lomé.

\section{Patients and Methods}

This is a multicentre, descriptive study based on patients' hospital records covering a 16-year period, from January 2004 to December 2020, conducted in the three departments of rheumatology (the Sylvanus Olympio Teaching Hospital; the Regional Hospital of Lomé and the Bè Hospital) all located in Lomé, the capital of Togo (West Africa). Socio-demographic, clinical, bacteriological, and radiological data were available in the patient's folders. We included in this 
study only patients with complete laboratory and radiological data. We excluded patients with the following conditions: hip replacement surgery; avascular necrosis of the femoral head; symptomatic arthritis of the hip due to rheumatoid arthritis, spondyloarthropathy, neuropathic arthropathy, or seronegative arthritis; malignancy, and rapidly destructive osteoarthropathy of the hip. The diagnosis of SAH was mainly based on clinical and radiological features. Infection is confirmed in case of positive culture results or typical histopathological features. Infection is probable in case of strong clinical suspicion such as good response to antibiotic therapy and the presence of at least three of the following: fatigue, anorexia, weight loss and anaemia. Plain X-ray, Full Blood Count (FBC), Erythrocyte Sedimentation Rate (ESR) and Human Immunodeficiency Virus (HIV) serology were systematically performed in all patients. Fever was defined as any body temperature above $37.5^{\circ}$ Celsius and leucocytosis as a White Blood Cells (WBC) count above $11,000 / \mathrm{mm}^{3}$. An ESR of more than $20 \mathrm{~mm}$ per hour was considered raised. Computed tomography scan (CT scan) was done in patients with no obvious signs of infection on plain X-ray. Magnetic resonance imaging was not performed in any of the patients. Neither synovial biopsy nor arthrocentesis were performed. In the absence of bacteriological confirmation, the presumptive etiological diagnosis was based on socio-demographic data, contact with a person with tuberculosis, the presence of high-grade fever, the mode of onset, the patient's general appearance, and the positivity of the tuberculin skin test. Patients with probable tuberculosis $\mathrm{SAH}$ received anti-tuberculosis drugs for 12 months, while those with bacterial SAH received a triple broad spectrum antibiotic therapy for two months. Upon hospital discharge, patients were followed-up once monthly. The data was collected using Epi info 7.0 and statistical analysis was performed using STATA/IC 11.0.

\section{Results}

Out of 3776 patients hospitalized in the three departments over the study period, 705 (18.67\%) were diagnosed with septic arthritis of which $70(9.92 \%)$ patients with SAH. The 70 patients with SAH were 44 (62.86\%) females, and $26(37.14 \%)$ males (Table 1), with a sex ratio of $1.7 \mathrm{~F} / \mathrm{M}$. The mean age of the patients was $42.43 \pm 19.37$ years (range: 5 years and 80 years) and mean duration of symptoms was $6.57 \pm 8.85$ months (range: 2 days and 48 months). The pain was inflammatory in nature in $46(65.71 \%)$ patients (Table 2 ) and the onset of the disease was progressive in $50(71.43 \%)$ patients. The pain was localized to the right hip of $48(68.57 \%)$ patients, to the left hip of $20(28.57 \%)$ patients and bilateral of the two $(2.86 \%)$ others. Sixty four patients $(91.43 \%)$ were limping and six (08.57\%) were crippled. Weight loss was noted in 38 (54.29\%) patients.

A risk factor was identified in $63(90.00 \%)$ patients. They were chronic alcohol abuse (34.29\%), poor hygiene (24.29\%), sickle cell disease (18.57\%), HIV infection $(7.14 \%)$, and diabetes $(05.71 \%)$. The mean body mass index was $21.95 \pm$ $4.07 \mathrm{~kg} / \mathrm{m}^{2}$ (range: $15.94 \mathrm{~kg} / \mathrm{m}^{2}$ and $30.66 \mathrm{~kg} / \mathrm{m}^{2}$ ). The average admission temperature was $37.74^{\circ} \pm 0.33^{\circ}$ Celsius (range: $36.6^{\circ}$ Celsius and $37.9^{\circ}$ Celsius). The 
mean ESR was $73.96 \pm 34.51 \mathrm{~mm} / \mathrm{hr}$ (range: $15 \mathrm{~mm} / \mathrm{hr}$ and $150 \mathrm{~mm} / \mathrm{hr}$ ). The mean haemoglobin level was $10.78 \pm 2.27 \mathrm{~g} / \mathrm{dl}$ (range: $4.4 \mathrm{~g} / \mathrm{dl}$ and $14.2 \mathrm{~g} / \mathrm{dl}$ ). The mean WBC count was $8651.03 \pm 6271.81 / \mathrm{mm}^{3}$ (range: $2600 / \mathrm{mm}^{3}$ and $\left.35,500 / \mathrm{mm}^{3}\right)$. The mean platelet cells count was $245,687 \pm 140,364.21 / \mathrm{mm}^{3}$ (range: $280,000 / \mathrm{mm}^{3}$ and $569,000 / \mathrm{mm}^{3}$ ). The mean C-reactive protein was 19.5 $\pm 18.63 \mathrm{mg} / \mathrm{l}$ (range: $6 \mathrm{mg} / \mathrm{l}$ and $48 \mathrm{mg} / \mathrm{l}$ ). The HIV serology was positive in five (7.14\%) out of the 70 patients. The mean serum creatinine was $9.96 \pm 2.87 \mathrm{mg}$ (range: $6 \mathrm{mg}$ and $17 \mathrm{mg}$ ). The average fasting blood sugar was $0.88 \pm 0.14 \mathrm{~g} / \mathrm{l}$ (range: $0.62 \mathrm{~g} / \mathrm{l}$ and $1.17 \mathrm{~g} / \mathrm{l}$ ). Radiologic features suggestive of SAH were identified on plain X-ray (Figure 1) in $55(78.57 \%)$ patients and on CT scan (Figure $2)$ in $15(21.43 \%)$ patients. The diagnosis of SAH was probable tuberculosis in 46 (65.71\%) patients and probable pyogenic bacterial in 24 (34.29\%) patients. All the $46(65.71 \%)$ patients with probable tuberculosis successfully completed twelve months of anti-tuberculosis therapy with no mortality; while two (8.33\%) of the 24 patients with bacterial SAH, died before completion of the 2 months triple broad spectrum antibiotic therapy. The outcome was therefore favourable in $68(97.14 \%)$ patients.

Table 1. Socio-demographic data of patients with septic arthritis of the hip.

\begin{tabular}{ccc}
\hline Characteristics & Number of patients & Percentage \\
\hline Sex & 44 & 62.86 \\
Female & 26 & 37.14 \\
Male & & \\
\hline Residential area & 46 & 65.71 \\
\hline Urban & 24 & 34.29 \\
Rural & & \\
\hline Occupation & 35 & 50.00 \\
Trader & 16 & 22.86 \\
Unskilled worker & 9 & 12.86 \\
Student & 6 & 08.57 \\
Civil servant & 4 & 05.71 \\
Farmer & &
\end{tabular}

Table 2. Distribution of patients according to clinical signs.

\begin{tabular}{ccc}
\hline & Number of patients & Percentage \\
\hline Reasons for the consultation & & \\
\hline Groin pain only & 25 & 35.71 \\
Great trochanter pain & 15 & 21.43 \\
Groin and low back pain & 14 & 20.00 \\
Groin and great trochanter pain & 9 & 12.86 \\
Groin and buttock pain & 7 & 10.00 \\
\hline Onset & & \\
\hline Progressive & 50 & 71.43 \\
Sudden & 20 & 28.57 \\
\hline
\end{tabular}




\section{Continued}

\begin{tabular}{|c|c|c|}
\hline Characteristics of the & & \\
\hline Inflammatory & 46 & 65.71 \\
\hline Mechanical & 24 & 34.29 \\
\hline \multicolumn{3}{|c|}{ Hip joint involved } \\
\hline Right & 48 & 68.57 \\
\hline Left & 20 & 28.57 \\
\hline Bilateral & 2 & 2.86 \\
\hline \multicolumn{3}{|l|}{ Limping } \\
\hline Yes & 64 & 91.43 \\
\hline No & 6 & 8.57 \\
\hline \multicolumn{3}{|c|}{ Referred Pain to the thigh } \\
\hline Yes & 42 & 60 \\
\hline No & 28 & 40 \\
\hline \multicolumn{3}{|l|}{ Fever } \\
\hline Yes & 23 & 32.86 \\
\hline No & 47 & 67.14 \\
\hline \multicolumn{3}{|l|}{ Weight loss } \\
\hline Yes & 38 & 54.29 \\
\hline No & 32 & 45.71 \\
\hline \multicolumn{3}{|c|}{ Infection entry point } \\
\hline Yes & 0 & 0 \\
\hline No & 70 & 100 \\
\hline \multicolumn{3}{|c|}{ Tuberculosis contact person } \\
\hline Yes & 0 & 0 \\
\hline No & 70 & 100 \\
\hline \multicolumn{3}{|c|}{ General Appearance } \\
\hline Ill & 48 & 68.57 \\
\hline Well & 22 & 31.43 \\
\hline \multicolumn{3}{|c|}{ Amyotrophy of the quadriceps } \\
\hline Present & 48 & 68.57 \\
\hline Absent & 22 & 31.43 \\
\hline \multicolumn{3}{|l|}{ Ankylosis } \\
\hline Right & 48 & 68.57 \\
\hline Left & 20 & 28.57 \\
\hline Bilateral & 2 & 2.86 \\
\hline \multicolumn{3}{|c|}{ Lower limb shortening } \\
\hline Present & 53 & 75.71 \\
\hline Absent & 17 & 24.29 \\
\hline \multicolumn{3}{|l|}{ Lumbar syndrome } \\
\hline Present & 55 & 78.57 \\
\hline Absent & 15 & 21.43 \\
\hline
\end{tabular}




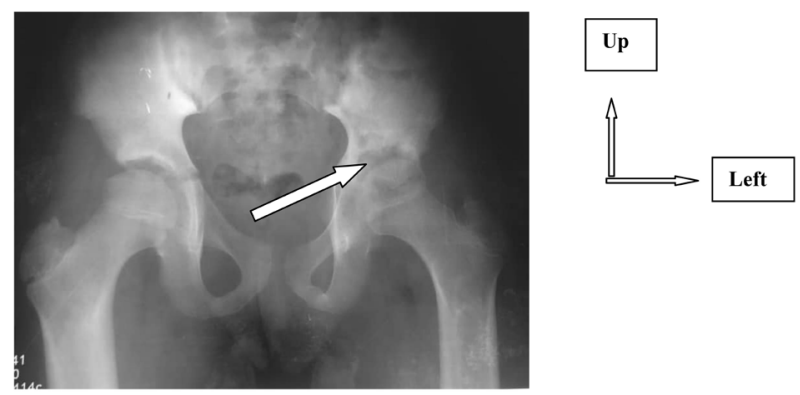

Figure 1. Anterior posterior radiograph of patient suffering from tuberculosis arthritis of the left hip with the joint space narrowing, and progressive bone erosion changes of both the left femoral head and the cortex of the acetabulum (white arrow).

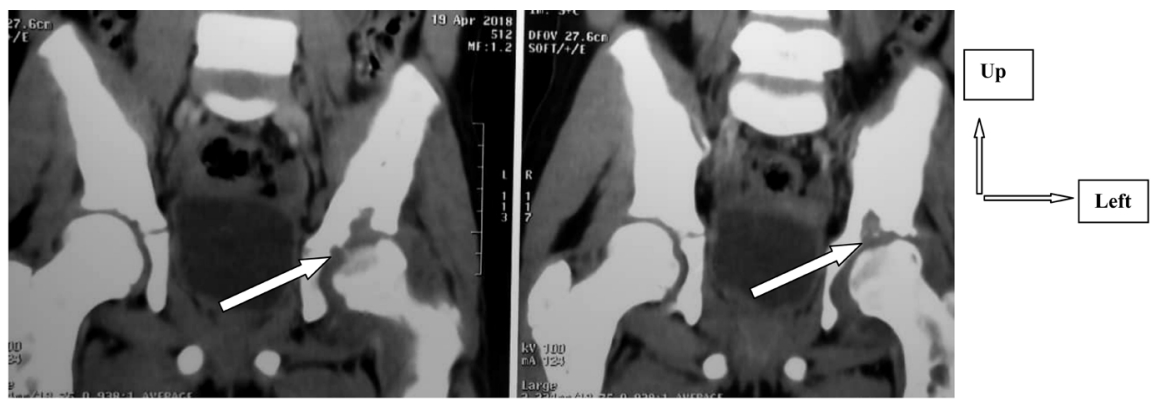

Figure 2. Computed Tomography of patient suffering from pyogenic bacterial arthritis of the left hip with erosion and narrowing of the joint space (white arrows).

\section{Discussion}

We reported only 70 cases of SAH over a 16-year period, representing $9.92 \%$ of infectious arthritis in rheumatology practice in Lome. This confirms the fact that infection of the hip joint is rare despite the high prevalence of infectious diseases in Africa [6] [7]. The above study, because of its shortcomings (hospital recruitments, narrowness of the technical platform) cannot be generalized to the whole Togolese population. Patients with septic arthritis are classified into three categories regarding definite diagnosis [8]: 1) those in whom a causative organism has been isolated from the synovial fluid; 2) those in whom a causative organism has been isolated remotely from the blood or from the swab of the infection entry point; and 3) those in whom no causative organism could be identified but whose clinical, laboratory markers of systemic inflammation and imaging data suggest a probable diagnosis, in particular fever, risk factors, absence of crystals in the synovial fluid, systemic inflammatory response syndrome, radiological features and complete response to empirical antibiotic therapy [9] [10] [11] [12]. All our patients were diagnosed with probable SAH since no germ was isolated due to limited laboratory support and antibiotic therapy prior to referral to our facilities [5] [13].

The mean age of 42, 43 years in our series is in keeping with reports from West African countries regarding the preponderance of septic arthritis in the fourth decade of life [14] [15] [16] [17]. This is in contrast with reports from 
Western countries, where septic arthritis mostly occurs in people in their sixties [17]. The relatively young age of the patients in our series could be explained by the demographic pattern of the African population as compared to that of Western countries, where most cases of SAH occur after hip replacement in elderly people [18] [19] [20] [21] [22].

There was a delay to SAH diagnosis in our series with a mean duration of symptoms of 6.57 months. Similarly, significant delay has been observed in the diagnosis of septic arthritis irrespective of the joints involved in many series [5] [13] [23] [24].

Alcohol abuse was the commonest risk factor (34.29\%) in our series, followed by poor hygiene $(24.29 \%)$ and sickle cell disease (18.57\%). Poor hygiene is an important risk factor for septic arthritis in most African series [5] [17] [23] [25] [26]. Continuous education on good hygiene and sanitation should be undertaken among African population.

Tuberculosis is responsible for $65.71 \%$ of SAH in our series. This is similar to results from other West African series [5] [16] [23] [26] and is in contrast to Western literature where bacteria causes were most common [1] [20] [22]. Tuberculosis is endemic in Sub-Saharan Africa but almost inexistant in Western countries where joint infections are secondary to manipulation during arthroplasties [1]. Campaign for the prevention and towards eradication of tuberculosis must be intensified on the African continent.

\section{Conclusion}

The hip remains a relatively rare localization of infectious pathologies. SAH preferentially affects young patients; and chronic alcohol abuse, poor hygiene and sickle cell disease are the most common risk factors in our series. Most cases of SAH are due to tuberculosis.

\section{Conflicts of Interest}

The authors declare no conflicts of interest regarding the publication of this paper.

\section{References}

[1] Dubost, J.J., Sauvezie, B. and Lequesne, M. (1998) Infectious Coxitis. Revue du Rhumatisme, 65, 227-235.

[2] Evrard, J. and Soudrie, B. (1993) Primary Septic Arthritis of Adult. International Orthopaedics, 17, 367-374.

[3] Rampon, S., Lopitaux, R., Meloux, J., Bussiere, J.L. and Leval, J.P. (1979) Septic Arthritis of the Hip: About 10 Observations. Rheumatology, 31, 363-368.

[4] Kaandorp, C.J.E., Dinant, H.J., Van de Laar, M.A.F.J., Moens, H.J.B., Prins, A.P.A. and Dijkmans, B.A.C. (1997) Incidence and Sources of Native and Prosthetic Joint Infection: A Community Based Prospective Survey. Annals of the Rheumatic Diseases, 56, 470-475. https://doi.org/10.1136/ard.56.8.470

[5] Houzou, P., Kakpovi, K., Fianyo, E., Koffi-Tessio, V.E.S., Tagbor, K.C., Landoh, 
D.E., Oniankitan, O. and Mijiyawa, M. (2017) Profile of Osteoarticular Infections in Rheumatology Consultation at Kara Teaching Hospital (Togo). European Scientific Journal, 13, 251-257.

[6] Nzenzé, J.R., Belembaogo, E., Magne, E.C., Sanou, A.S., Coniquet, S., Moussavou-Kombila, J.R. and Bogui-Kouma, J.B. (2001) Panorama of Inflammatory Arthropathies in Libreville, Serie's Analysis of 57 Observations. Medicine of Black Africa, 48, 399-402.

[7] Bileckot, R., Koubemba, G., Nkoua, J.L., Bileckot, R., Koubemba, G. and Nkoua, J.L. (1999) Aetiology of Oligoarthritis in Equatorial Africa. A Retrospective Study of 80 Cases in Brazzaville, Congo. La Revue de Médecine Interne, 20, 408-411.

[8] Gupta, M.N., Sturrock, R.D. and Field, M. (2001) A Prospective 2-Year Study of 75 Patients with Adult-Onset Septic Arthritis. Rheumatology, 40, 24-30.

https://doi.org/10.1093/rheumatology/40.1.24

[9] Kaushik, P., Malaviya, A.N. and Rotimi, V.O. (1999) Infective Arthritis in Adults-Experience at a Teaching Hospital in Kuwait. Rheumatology International, 19, 1-5.

[10] Ryan, M.J., Kavanagh, R., Wall, P.G. and Hazleman, B.L. (1997) Bacterial Joint Infections in England and Wales: Analysis of Bacterial Isolates over a Four-Year Period. Rheumatology, 36, 370-373. https://doi.org/10.1093/rheumatology/36.3.370

[11] Dubost, J.J., Soubrier, M. and Sauvezie, B. (2000) Pyogenic Arthritis in Adults. Joint Bone Spine, 67, 11-21.

[12] Schlapbach, P., Ambord, C., Blochlinger, A.M. and Gerber, N.J. (1990) Bacterial Arthritis: A Fever, Rigors, Leucocytosis and Blood Cultures of Diagnostic Value? Clinical Rheumatology, 9, 69-72.

[13] Ntsiba, H., Makosso, E., Ngandeu-Singwé, M. and Yala, F. (2006) Septic Arthritis in Tropical Environment. 176 Cases Report in Brazzaville. Mali Medical, 21, 49-53.

[14] Houzou, P., Koffi-Tessio, V.E.S., Kakpovi, K., Fianyo, E., Tagbor, K.C., Oniankitan, O. and Mijiyawa, M. (2017) Panorama of Inflammatory Arthropathies in Rheumatologic Consultation in Northern-Togo. Journal Autoimmune Disorders, 3, 49.

[15] Ouédraogo, D.-D., Ntsiba, H., Tiendrébéogo/Zabsonré, J., Tiéno, H., Bokossa, L.I.F., Kaboré, F. and Drabo, J. (2014) Clinical Spectrum of Rheumatologic Diseases in a Department of Rheumatology in Ouagadougou (Burkina Faso). Clinical Rheumatology, 33, 385-389. https://doi.org/10.1007/s10067-013-2455-4

[16] Eti, E., Daboiko, J.C., Debauly, S., Ouali, B., Ouattara, B., Yao, N., Gabla, A. and Kouakou, N.M. (2000) Pyogenic Arthritis of the Arms at Cocody Teaching Hospital: About 79 Cases. Rheumatology, 52, 18-21.

[17] Ogunlusi, J.D. (2006) Septic Arthritis in a Nigerian Tertiary Hospital. The Iowa Orthopedic Journal, 26, 45-47.

[18] Laurent, E., Gras, G., Druon, J., Rosset, P., Baron, S., Le-Louarn, A., Rusch, E., Bernard, L. and Grammatico-Guillon, L. (2018) Key Points of Osteoarticular Infections since the Labelling of Reference Centres in France. Medicine and Infectious Diseases, 48, 256-262.

[19] Nemes, S., Gordon, M., Rogmark, C. and Rolfson, O. (2014) Projections of Total Hip Replacement in Sweden from 2013 to 2030. Acta Orthopaedica, 85, 238-243. https://doi.org/10.3109/17453674.2014.913224

[20] Grammatico-Guillon, L., Baron, S., Gettner, S., Lecuyer, A-I., Gaborit, C., Rosset, P. and Rusch, E. (2012) Bone and Joint Infections in Hospitalized Patients in France, 2008: Clinical and Economic Outcomes. The Journal of Hospital Infection, 82, 
40-48. https://doi.org/10.1016/j.jhin.2012.04.025

[21] Grammatico-Guillon, L., Baron, S., Rosset, P., Gaborit, C., Bernard, L., Rusch, E. and Astagneau, P. (2015) Surgical Site Infection after Primary Hip and Knee Arthroplasty: A Cohort Study Using a Hospital Database. Infection Control and Hospital Epidemiology, 36, 1198-1207. https://doi.org/10.1017/ice.2015.148

[22] Zhao, Y., Fu, D., Chen, K., Li, G., Cai, Z., Shi, Y. and Yin, X. (2014) Outcome of Hemiarthroplasty and Total Hip Replacement for Active Elderly Patients with Displaced Femoral Neck Fractures: A Meta-Analysis of 8 Randomized Clinical Trials. PLoS ONE, 9, e98071. https://doi.org/10.1371/journal.pone.0098071

[23] Oniankitan, O., Bagayoko, Y., Fianyo, E., Koffi-Tessio, V., Kakpovi, K., Tagbor, K.C., Houzou, P. and Mijiyawa, M. (2011) Infectious Arthritis in Rheumatology Consultation in Lome (Togo). Medecine Tropicale, 71, 61-62.

[24] Mue, D.D., Salihu, M.N., Awonusi, F.O., Yongu, W.T., Kortor, J.N. and Elachi, I.C. (2013) The Epidemiology and Outcome of Acute Septic Arthritis: A Hospital-Based Study. Journal of the West African College of Surgeons, 3, 40-52.

[25] Zomalheto, Z., Avimadje, M., Gounongbe, M. and Dossou-Yovo, H. (2010) Factors Linked to Disco-Vertebral Disease of Tuberculosis in Cotonou. Le Benin Medical, 44, 30-32.

[26] Maftah, M., Lmejjat, M., Mansouri, A., El Abbadi, N. and Bellakhdah, F. (2001) Pott's Diseases about 320 Cases. Medecine du Maghreb, 90, 19-22. 